\title{
Learners' Transfer of Writing Skills Between Languages
}

One hundred, twenty-six secondary school EFL students took part in this study, which examines learners' transfer of essay organization skills between languages. Students were divided into three groups: (a) one receiving $L 1$ essay writing instruction; (b) another receiving equivalent L2 (English) instruction; and (c) a comparison group receiving no such instruction. This article analyses students' pre-and posttest essay organization and grammatical proficiency scores. It concludes that many learners transfer writing skills between languages, and that their success in doing so is assisted by their grammatical proficiency in the target language.

\section{Introduction}

This article discusses part of a research project that was undertaken among 126 secondary school students in Iceland. It examines these learners' ability to transfer newly learned essay writing skills between Icelandic and English, ${ }^{1}$ and attempts to establish whether their level of English grammatical proficiency ${ }^{2}$ affects such L1-to-L2 transfer.

Advanced EFL and ESL curricula often include the teaching of essay writing. However, research has not clarified whether instruction in such a demanding task might be more effectively carried out in students' first language where possible. As Ringbour (1992) states, "Lip service is sometimes paid to transfer in comprehension and to positive transfer, but hardly any systematic studies based on empirical data have been made" (p. 88).

Research in L2 reading by Clarke (1980) and Carrell (1991) presents strong evidence suggesting, as Alderson (1984) says, "that some sort of threshold or language competence ceiling has to be attained before existing abilities in the first language can begin to transfer" (p. 20). In the field of writing, preliminary studies by Yau (1987) indicate that transferability of writing skills requires a similar threshold of second language grammatical competence as reported in the reading research. Uzawa and Cumming (1989) found that the writing behaviors of their foreign language learners of Japanese were "uni-

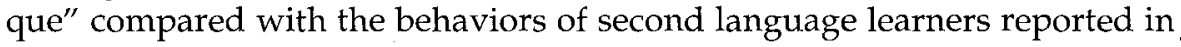
the literature. Their foreign language students displayed "a kind of mental dialectic" between composing processes in their first and foreign languages, as they struggled between, on the one hand, their desire to "keep up the standard" that they were used to achieving in their L1 writing and, on the 
other hand, the pragmatic necessity of "lowering their standards" when writing in Japanese, in order to complete something in a reasonable amount of time (pp. 185-186).

Cummins' (1991a) interdependence hypothesis seems to contradict the findings of researchers mentioned above:

To the extent that instruction in Lx is effective in promoting proficiency in $\mathrm{Lx}$, transfer of this proficiency to Ly will occur provided there is adequate exposure to Ly (either in school or environment) and adequate motivation to learn Ly. (p. 77)

Of course the caveats "adequate exposure" and "adequate motivation" may remove the contradiction. Cummins (1991b) also reviews a number of Scandinavian and North American studies that support his view that schoolage learners who develop what he refers to as "decontextualized language skills" through their first language tend to develop similar skills in their second language. A study by Cumming (1990) of 23 Francophone Canadian adults strongly supports this view, and moreover makes the point that grammatical proficiency was not a factor in his participants' ability to transfer writing skills between languages: "People simply enacted composing strategies, characteristic of their mother tongue expertise, in their second language" (p. 122).

It is conceivable that whatever thoughts a writer generates before writing can be expressed in a variety of ways not tied to a particular language. It would follow that, to the extent that thoughts are transferable across languages, people should be able to apply the skills and knowledge that they have acquired in first language writing to their L2 writing. In an L1 context, Scardamalia (1981) offers the appealing suggestion that children should be able to convey complex thoughts through simple vocabulary and elementary sentences just as well as through difficult words and complex sentences. An implication of this notion for the issue of transfer is that writers would not need to be as proficient in their L2 as in their first language in order to employ their L1 thinking skills in their L2 writing.

However, studies by Yau (1987) and Uzawa and Cumming (1989) present reason to suspect that grammatical proficiency may play a part in people's ability to transfer their writing skills from one language to another. Perhaps some foreign language writers, like the "low road" ${ }^{3} \mathrm{~L} 1$ writers described by Bereiter and Scardamalia (1983), need to devote more of their memory capacity to finding the right words and structures, leaving less mental capacity to deal with global planning.

A disagreement exists, then, between those who suggest that students' L2 . grammatical proficiency plays a part in their ability to transfer reading or writing skills between languages, and those who either do not acknowledge L2 grammatical proficiency as a major factor or who contend that it plays no 
part in such transfer. The research questions addressed were therefore as follows: (a) Do Icelandic secondary school students transfer essay writing skills newly gained in Icelandic to their English writing? and (b) Does their level of English grammatical proficiency affect their ability to transfer these writing skills?

Iceland was an ideal location to base the study for, although Icelandic is very much the nation's first language, English is the language of the movies, much television programming, ${ }^{4}$ and a great deal of the popular music, meaning that Icelanders are exposed to English, to use Cummins' term. Not only is English prevalent, but it is also held in high regard by society, and Icelanders are motivated to learn the language. ${ }^{5}$ However, Icelanders' grammatical proficiency in English varies greatly, as one would expect in a country where people are not in any formal sense (except in school) required to know this foreign language.

The homogeneity of Icelandic EFL learners-the relative lack of diversity of their education, socioeconomic status, and language background-was also an advantage in locating the study in Iceland. This lack of diversity (unlike the situation among ESL learners in North America, for example) meant that students' writing ability and English grammatical proficiency would not be confounded with myriad other variables such as length of residency in the country, language of the community, and so forth.

Finally, basing the study in Iceland meant that contrastive rhetoric need not be an issue. Many L2 writing studies examining learners' written product have purported to show distinct and sometimes culturally inappropriate rhetorical patterns surfacing in learners' English writing as a result of students" "negative transfer" of discourse conventions from their L1. ${ }^{6}$ It would be folly to claim that all written discourse conventions in all written. genres are similar in Icelandic and English, but secondary school essay writing instruction is similar in Icelandic and EFL secondary school curricula in Iceland, and no apparent differences exist between the essay models that are presented in the two language classrooms. ${ }^{7}$

As far as essay organization is concerned, model Icelandic secondary school persuasive essays possess the following features:

Thesis: A guiding idea is stated near the beginning of the essay.

Argument: A point of view consistent with the thesis is argued through reference to relevant evidence and / or through other relevant appeals to emotion or logic.

Conclusion: A conclusion is stated that either presents the essay's gist or restates its thesis. 
These organizational features are much the same as those of the English secondary school essay, certainly as the genre is taught in Iceland.

\section{Research Design}

Participants

One hundred and twenty-six 17- to 18-year-old students at three schools took part in the study. They were attending their second year of upper-secondary school (upper-secondary school begins at age 16 and lasts four years). One class at each of the three schools was randomly assigned to receive Icelandic instruction in persuasive essay writing; together these 40 students comprised Group L1. A second class at each school was assigned to receive similar instruction in English (Group L2; n=46). Finally, a third class at each school received no essay writing instruction (the comparison group; $n=40$ ). Table 1 shows the distribution of students. ${ }^{8}$

All students had received some essay writing instruction in Icelandic in the first year of their secondary school studies. The additional, highly focused, essay writing instruction received by students in Groups L1 and L2 during this study was not a normal component of the second year curriculum. Thus no ethical question arose with some students receiving essay writing instruction and others receiving none.

All groups were similar in terms of mean age (about 17.5) and malefemale ratio (about 1:2). At each school, one English teacher taught all three EFL classes. One teacher taught all L1 classes at School II, but two L1 teachers were involved at each of the other schools: one teaching essay instruction and the other teaching the regular Icelandic language curriculum. Regardless of their treatment (or group), all 126 students followed the same basic Icelandic and English language curricula, though students in Groups L1 and L2 received essay writing instruction in lieu of other writing practice such as letter and journal writing (or, in Icelandic, in some cases instead of stylistics). Regular English instruction included grammar and literature classes and

Table 1

Distribution of Participants by School and Treatment

\begin{tabular}{lcccc}
\hline & School I & School II & School III & Total \\
\hline L1 Teaching & 22 & 9 & 9 & 40 \\
L2 Teaching & 26 & 9 & 11 & 46 \\
Comparison & 18 & 9 & 13 & 40 \\
\hline Total & 66 & 27 & 33 & 126 \\
\hline
\end{tabular}


opportunities to practice speaking and listening. The regular Icelandic instruction also included classes in L1 grammar and literature.

\section{Essay Writing Lessons}

The study was to some extent a collaborative project undertaken with a number of teachers in Iceland. The goal was to work cooperatively with local educators so that they would be inclined to incorporate the study's findings into their teaching. To that end, the experimental intervention employed in the study is intentionally based on the teaching approach currently employed in Icelandic schools. Teachers were recruited who were interested in teaching writing, and their ideas and approaches were incorporated into the study's design. I neither apologize for nor advocate the teaching approach that was employed in this study. However, the actual 14-class/10-lesson course, as outlined in Appendix I, is not recommended, for it was far too perfunctory and was seen as such by the teachers involved. (Unfortunately, only 14 lessons could be spared for this study from the students' busy timetable.)

It may be noted in Appendix I that of the 14 (50-minute) "essay-writing classes" taken by Groups L1 and L2:

1. Four were taken up administering the pre- and posttests.

2. Six were devoted to instruction (lectures, group, and individual seatwork).

3. Four were devoted to actual in-class writing.

In addition, each student wrote three draft persuasive essays. Each of these was handed in, commented on by the teacher, and returned to the student, who rewrote it. It was then handed back to the teacher, who commented on it again and handed it back.

To confirm that the teaching conformed to the research design, all classes were observed and audiotaped once, teaching materials were examined, and 27 students and all teachers were interviewed.

\section{Pre-and Posttests}

Before the study, various English essay topics were piloted on 100 Icelandic 17- and 18-year-olds. The particular topics chosen for this study are those that were found to be equally well answered in the pilot, using holistic scoring. Icelandic topics were not piloted; instead, Icelandic teachers recommended topics and two of these were chosen. English and Icelandic topics were therefore not the same. They are shown in Appendix II.

Both the English and Icelandic pre- and posttests were timed (40-minute) essays and were counterbalanced, with about half of the randomly selected students writing Test A (i.e., Essay Topic A) as pre-test, followed by Test B as posttest. The other half of the students wrote $B$ as pre-test and $A$ as posttest. 
Rating Pre- and Posttests

Two experienced EFL teachers and two experienced L1 teachers were trained to score the essays. These independent experts scored the pre- and posttest essays blind, ${ }^{9}$ using a scoring guide that had been piloted in Iceland in advance of this study to reflect the particular characteristics of the persuasive essay as it is written by this population.Various features of the genre (Thesis, Argument, Conclusion, Register, Paragraphs, Transition Expressions) were scored between 0 and 4, a 5-point scale that had the advantage of matching the E-to-A grades with which raters were familiar. A score for Organization was calculated by adding the scores for the features Thesis, Argument, and Conclusion. A separate 0-to-4 holistic score for Grammar was also awarded to each essay. The relevant sections of the scoring guide are outlined in Appendix III. The length (number of words) of each essay was also calculated.

\section{Results}

\section{Interrater Reliability: Icelandic and English Essay Scores}

Interrater reliability was assessed for both the Icelandic and English essays. As shown in Appendix IV, Pearson correlations of the raters' scores were satisfactory, all being over 0.7 for the component scores of Organization. The researcher personally rated a random sample of the Icelandic and English essays and found that these scores correlated satisfactorily $(r>0.7)$ with the mean of the two raters' scores. Therefore, the mean of the raters' scores were used in all analyses.

\section{Factor Analysis of the Icelandic and English Essay Scores}

Factor analyses (Appendix V) of both the Icelandic and English essay scores suggest that all of the features may be grouped into three general factors, which I have termed (a) Organization, (b) Fluency, and (c) Length. The most important outcome of these analyses is the finding that the scores for most features were not overly influenced either by an essay's display (or lack) of fluency, nor by its length. In other words, the raters scored what they were supposed to score and were not distracted, for example, by written errors or verbosity. An exception is the score for Argument in the English essays, which is somewhat related to all three factors-Organization, Fluency, and Length. ${ }^{10}$

\section{Test $A$ and Test $B$ Equivalence}

$T$-tests carried out on the English and Icelandic pretest scores established that essay topics A and B were equally well answered. Pre-test scores for all features, as well as for Grammar and Length, showed no statistically significant differences between the two different topics. 
The Effect of Language of Instruction on

English Essay Organization

As shown in Table 2, larger gains were made by Group L1 and Group L2 than by the comparison group in all English organizational features. Group L2's mean Organization score rose by 1.56 (out of a possible 12), compared with a gain of 1.47 by Group L1 and 0.64 by the comparison group. On the other hand, gains in Length and Grammar did not differ noticeably between any groups. Multiple regression analyses ${ }^{11}$ of the test scores (see Appendix $\mathrm{V}-\mathrm{A}$ ) showed that the mean Organization score gain made by the students taught in English-but not by those taught in Icelandic-was significantly higher $(\mathrm{p}<.01)$ than the mean gain of the comparison group.

\section{The Effect of Language of Instruction on}

\section{Icelandic Essay Organization}

Table 3 shows that larger gains were made by Group L1 and Group L2 than by the comparison group on most Icelandic organizational features. Considering the Icelandic essays' Organization score as a whole, Group L1 rose by a mean of 1.64, compared to a mean gain of 1.21 by Group L2 and a loss of -0.19 by the comparison group. Again, gains in essay length did not differ

Table 2

Mean English Pre- and Posttest Scores ( $n=126)$

\begin{tabular}{|c|c|c|c|c|c|c|c|}
\hline \multirow[t]{2}{*}{ Instruction: } & & \multicolumn{2}{|c|}{$L 1(n=40)$} & \multicolumn{2}{|c|}{$L 2(n=46)$} & \multicolumn{2}{|c|}{ Comp. $(n=40)$} \\
\hline & & mean & $\sigma$ & mean & $\sigma$ & mean & $\sigma$ \\
\hline \multirow[t]{3}{*}{ Thesis } & Pre & 1.77 & 1.21 & 2.09 & 1.06 & 1.93 & 0.92 \\
\hline & Post & 2.50 & 1.06 & 2.62 & 0.83 & 2.04 & 0.99 \\
\hline & Gain & 0.73 & 1.26 & 0.52 & 1.21 & 0.11 & 1.40 \\
\hline \multirow[t]{3}{*}{ Argument } & Pre & 2.04 & 0.93 & 2.01 & 0.96 & 1.88 & 0.80 \\
\hline & Post & 2.24 & 0.94 & 2.25 & 1.03 & 1.96 & 0.88 \\
\hline & Gain & 0.20 & 1.24 & 0.24 & 1.24 & 0.08 & 1.11 \\
\hline \multirow[t]{3}{*}{ Conclusion } & Pre & 1.35 & 1.26 & 1.62 & 1.43 & 1.14 & 1.11 \\
\hline & Post & 1.90 & 1.28 & 2.42 & 1.27 & 1.59 & 1.23 \\
\hline & Gain & 0.55 & 1.46 & 0.80 & 1.68 & 0.45 & 1.68 \\
\hline \multirow[t]{3}{*}{ ORGANIZATION } & Pre & 5.16 & 2.90 & 5.73 & 2.70 & 4.95 & 1.97 \\
\hline & Post & 6.63 & 2.70 & 7.29 & 2.63 & 5.59 & 1.98 \\
\hline & Gain & 1.47 & 3.03 & $1.56^{\star}$ & 3.09 & $0.64^{*}$ & 2.86 \\
\hline \multirow[t]{3}{*}{ Grammar } & Pre & 2.31 & 1.14 & 2.20 & 1.26 & 2.01 & 1.00 \\
\hline & Post & 2.44 & 1.10 & 2.54 & 1.10 & 2.39 & 0.99 \\
\hline & Gain & 0.13 & 1.05 & 0.34 & 0.94 & 0.38 & 1.03 \\
\hline \multirow[t]{3}{*}{ Length (Words) } & Pre & 201 & 75 & 202 & 82 & 203 & 66 \\
\hline & Post & 237 & 69 & 257 & 65 & 241 & 83 \\
\hline & Gain & 36 & 83 & 55 & 79 & 38 & 62 \\
\hline
\end{tabular}


Table 3

Mean Icelandic Pre- and Posttest Scores $(n=99)^{12}$

\begin{tabular}{|c|c|c|c|c|c|c|c|}
\hline \multirow[t]{2}{*}{ Instruction: } & & \multicolumn{2}{|c|}{$L 1(n=31)$} & \multicolumn{2}{|c|}{$L 2(n=37)$} & \multicolumn{2}{|c|}{ Comp. $(n=31)$} \\
\hline & & mean & $\sigma$ & mean & $\sigma$ & mean & $\sigma$ \\
\hline Thesis & $\begin{array}{l}\text { Pre } \\
\text { Post } \\
\text { Gain }\end{array}$ & $\begin{array}{l}2.28 \\
2.85 \\
0.57^{\star}\end{array}$ & $\begin{array}{l}1.15 \\
0.87 \\
1.23\end{array}$ & $\begin{array}{l}2.31 \\
2.80 \\
0.48 \#\end{array}$ & $\begin{array}{l}0.98 \\
0.82 \\
1.25\end{array}$ & $\begin{array}{l}2.36 \\
2.39 \\
0.03^{\star} \#\end{array}$ & $\begin{array}{l}1.07 \\
0.98 \\
1.43\end{array}$ \\
\hline Argument & $\begin{array}{l}\text { Pre } \\
\text { Post } \\
\text { Gain }\end{array}$ & $\begin{array}{l}2.06 \\
2.56 \\
0.50\end{array}$ & $\begin{array}{l}0.98 \\
0.95 \\
1.26\end{array}$ & $\begin{array}{l}2.19 \\
2.30 \\
0.11\end{array}$ & $\begin{array}{l}1.00 \\
0.96 \\
1.32\end{array}$ & $\begin{array}{l}2.14 \\
2.28 \\
0.14\end{array}$ & $\begin{array}{l}0.84 \\
0.77 \\
1.12\end{array}$ \\
\hline Conclusion & $\begin{array}{l}\text { Pre } \\
\text { Post } \\
\text { Gain }\end{array}$ & $\begin{array}{l}1.86 \\
2.44 \\
0.57^{\star}\end{array}$ & $\begin{array}{l}1.05 \\
1.15 \\
1.60\end{array}$ & $\begin{array}{l}1.85 \\
2.47 \\
0.62 \#\end{array}$ & $\begin{array}{l}1.25 \\
1.02 \\
1.50\end{array}$ & $\begin{array}{c}2.04 \\
1.67 \\
-0.36^{\star} \#\end{array}$ & $\begin{array}{l}1.11 \\
1.24 \\
1.68\end{array}$ \\
\hline ORGANIZATION & $\begin{array}{l}\text { Pre } \\
\text { Post } \\
\text { Gain }\end{array}$ & $\begin{array}{l}6.21 \\
7.85 \\
1.64^{*}\end{array}$ & $\begin{array}{l}2.11 \\
2.29 \\
2.83\end{array}$ & $\begin{array}{l}6.34 \\
7.57 \\
1.21 \#\end{array}$ & $\begin{array}{l}2.66 \\
2.18 \\
3.23\end{array}$ & $\begin{array}{c}6.54 \\
6.35 \\
-0.19^{\star} \#\end{array}$ & $\begin{array}{l}2.30 \\
2.22 \\
3.01\end{array}$ \\
\hline Length (Words) & $\begin{array}{l}\text { Pre } \\
\text { Post } \\
\text { Gain }\end{array}$ & $\begin{array}{r}205 \\
254 \\
49\end{array}$ & $\begin{array}{l}65 \\
64 \\
69\end{array}$ & $\begin{array}{r}255 \\
258 \\
3\end{array}$ & $\begin{array}{l}94 \\
71 \\
76\end{array}$ & $\begin{array}{r}226 \\
253 \\
27\end{array}$ & $\begin{array}{l}71 \\
74 \\
65\end{array}$ \\
\hline
\end{tabular}

\#\# Pairs of symbols denote means that are significantly different at the 0.05 level, as computed by the Multiple Range Test (LSD method) of the SPSS One-way procedure.

noticeably between any groups. ${ }^{13}$ Multiple regression analyses showed that pre- to posttest gains in Thesis and Conclusion, as well as in Organization as a whole, were significantly higher $(\mathrm{p}<.05)$ by the students taught both in Icelandic and English than by students in the comparison group.

The Effect of Writing Ability

Obviously, students who obtained high pre-test scores did not stand to make the same gains as those who obtained low scores. It is therefore useful to pay special attention to the performance of the less able writers, for example the learners whose English pre-test Organization scores were below 8 out of 12 . Group L1 contains 31 such students; Group L2, 36; and the comparison group, $37 .{ }^{14}$

As shown in Table 4, these less able writers-the students who had the most to gain from instruction-often did improve in their English essay organization as a result of either L1 or L2 instruction. Between pre- and posttest, Group L1 improved by an average of 2.51, Group L2 gained 2.26 and the comparison group made a mean gain of 1.01. A Multiple Range Test (least-significant difference procedure) of the SPSS One-way analysis of variance shows both Groups L1 and L2 to have made significantly $(\mathrm{p}<.05)$ different gains from the comparison group. 
Table 4

Less Able Writers' Mean English Pre- and Posttest Scores ( $n=104)$

\begin{tabular}{|c|c|c|c|c|c|c|c|}
\hline \multirow[t]{2}{*}{ Instruction: } & & \multicolumn{2}{|c|}{$L 1(n=31)}$. & \multicolumn{2}{|c|}{$L 2(n=36)$} & \multicolumn{2}{|c|}{ Comp. $(n=37)$} \\
\hline & & mean & $\sigma$ & mean & $\sigma$ & mean & $\sigma$ \\
\hline Thesis & $\begin{array}{l}\text { Pre } \\
\text { Post } \\
\text { Gain }\end{array}$ & $\begin{array}{l}1.38 \\
2.38 \\
1.00^{*}\end{array}$ & $\begin{array}{l}1.03 \\
1.11 \\
1.20\end{array}$ & $\begin{array}{l}1.81 \\
2.56 \\
0.75\end{array}$ & $\begin{array}{l}0.93 \\
0.89 \\
1.13\end{array}$ & $\begin{array}{l}1.82 \\
2.13 \\
0.32^{*}\end{array}$ & $\begin{array}{l}0.86 \\
0.93 \\
1.21\end{array}$ \\
\hline Argument & $\begin{array}{l}\text { Pre } \\
\text { Post } \\
\text { Gain }\end{array}$ & $\begin{array}{l}1.65 \\
2.28 \\
0.62\end{array}$ & $\begin{array}{l}0.64 \\
0.91 \\
0.97\end{array}$ & $\begin{array}{l}1.76 \\
2.06 \\
0.29\end{array}$ & $\begin{array}{l}0.81 \\
1.03 \\
1.30\end{array}$ & $\begin{array}{l}1.84 \\
1.91 \\
0.07\end{array}$ & $\begin{array}{l}0.80 \\
0.88 \\
1.14\end{array}$ \\
\hline Conclusion & $\begin{array}{l}\text { Pre } \\
\text { Post } \\
\text { Gain }\end{array}$ & $\begin{array}{l}0.92 \\
1.81 \\
0.88\end{array}$ & $\begin{array}{l}1.05 \\
1.26 \\
1.34\end{array}$ & $\begin{array}{l}1.03 \\
2.25 \\
1.22\end{array}$ & $\begin{array}{l}0.97 \\
1.29 \\
1.59\end{array}$ & $\begin{array}{l}0.94 \\
1.57 \\
0.62\end{array}$ & $\begin{array}{l}0.91 \\
1.22 \\
1.61\end{array}$ \\
\hline ORGANIZATION & $\begin{array}{l}\text { Pre } \\
\text { Post } \\
\text { Gain }\end{array}$ & $\begin{array}{l}3.95 \\
6.46 \\
2.51 x\end{array}$ & $\begin{array}{l}2.00 \\
2.67 \\
2.35\end{array}$ & $\begin{array}{l}4.61 \\
6.87 \\
2.26 \#\end{array}$ & $\begin{array}{l}1.74 \\
2.72 \\
2.96\end{array}$ & $\begin{array}{l}4.61 \\
5.61 \\
1.01 x \#\end{array}$ & $\begin{array}{l}1.60 \\
1.97 \\
2.60\end{array}$ \\
\hline Grammar & $\begin{array}{l}\text { Pre } \\
\text { Post } \\
\text { Gain }\end{array}$ & $\begin{array}{l}2.15 \\
2.37 \\
0.21\end{array}$ & $\begin{array}{l}1.10 \\
1.21 \\
1.14\end{array}$ & $\begin{array}{l}2.03 \\
2.41 \\
0.38\end{array}$ & $\begin{array}{l}1.31 \\
1.12 \\
1.01\end{array}$ & $\begin{array}{l}2.02 \\
2.34 \\
0.32\end{array}$ & $\begin{array}{l}1.01 \\
1.01 \\
1.03\end{array}$ \\
\hline Length (Words) & $\begin{array}{l}\text { Pre } \\
\text { Post } \\
\text { Gain }\end{array}$ & $\begin{array}{r}182 \\
237 \\
54\end{array}$ & $\begin{array}{l}53 \\
74 \\
74\end{array}$ & $\begin{array}{r}191 \\
252 \\
61\end{array}$ & $\begin{array}{l}79 \\
62 \\
76\end{array}$ & $\begin{array}{r}202 \\
237 \\
36\end{array}$ & $\begin{array}{l}65 \\
84 \\
64\end{array}$ \\
\hline
\end{tabular}

"X\# Pairs of symbols denote means significantly different at the 0.05 level, as computed by the Multiple Range Test (LSD) of the SPSS One-way procedure.

The Effect of English Grammatical Proficiency

Table 5 reveals the interesting effects observed when students are subdivided according to their English grammatical proficiency. The effects of grammatical proficiency can first be analyzed by splitting the 104 less able essay writers into two groups, the 53 who obtained an averaged grammar score ${ }^{15}$ of less than or equal to 2.25 out of four (the less able writers with poor Grammar) and the 51 whose averaged grammar scores were greater than 2.25 (the less able writers with better Grammar). The less able writers with poor Grammar made a mean gain of 1.48 points in their Organization score between pre- and posttest, whereas the less able writers with good Grammar gained a mean of 2.32. (From here on, students' averaged pre- and posttest grammar score will be referred to as simply their grammar score.)

The difference between the mean gains of the two grammatical proficiency groups is especially interesting in view of the fact that those with low grammar scores also tended to receive low pre-test Organization scores, ${ }^{16}$ meaning that although the less able writers with poor Grammar were among those who stood to gain the most in terms of improved organization over the 
Table 5

Organization Score Gains of Less Able Writers

Separated by Level of Grammar Score

(Gain=Posttest minus pre-test score) $n=104$

\begin{tabular}{lrrr}
\hline (Averaged) Grammar Score & Pre-test & Gain & $\sigma$ \\
Poor $(\leq 2.25) n=53$ & 4.27 & 1.48 & 2.41 \\
Better $(>2.25) \quad n=53$ & 4.56 & 2.32 & 2.97 \\
\hline
\end{tabular}

research period, it seems that some may have been held back by their poor grammatical proficiency.

As shown in Table 6, the combined effects of grammatical proficiency plus language of instruction creates a complex pattern. On the one hand, it appears that grammatical proficiency was not a crucial factor among the students taught in English. The mean gain in the Organization score made by the 18 less able writers with poor Grammar who were taught in English was 2.15 , a gain not very much less than the 2.37 gained by the 18 less able writers with better Grammar.

On the other hand, among the students taught in Icelandic, it appears that their English grammatical proficiency may have influenced the posttest gain of their English Organization scores. In Group L1, the mean gain made by the 15 less able writers with poor Grammar was 1.92, which is substantially less than the gain of 3.06 made by the 16 less able writers with better Grammar.

\section{Discussion}

Over the short research period of this study, the secondary school EFL students taught essay writing in English improved in their English essay organization to a significantly greater extent than those not taught essay writing. On the other hand, students taught in their L1 also improved in their English writing, though not with gains significantly different from those of the students in the comparison group.

The study also indicates that learners' transfer of writing skills from their L1 to English depends on their English grammatical proficiency. However, this indication was perhaps heralded by the former result. That is to say, students' transfer of writing skills was not as evident into the L2 (a language in which some students were not grammatically proficient) as was such transfer into the L1 (in which the students were all grammatically proficient).

Of course, we have to be careful not to jump to the conclusion on the basis of these results that it is necessarily more effective to teach EFL writing in English than in students' L1, for it is difficult to make such a claim based on 
Table 6

Organization Score Gains of Less Able Writers ( $n=104)$

Separated by Language of Instruction

(Gain=Posttest score minus pre-test score)

\begin{tabular}{|c|c|c|c|c|c|c|c|}
\hline $\begin{array}{l}\text { Language } \\
\text { of instruction }\end{array}$ & $\begin{array}{l}\text { Org. } \\
\text { Pretest }\end{array}$ & $\begin{array}{l}\text { Org } \\
\text { Gain }\end{array}$ & $\sigma$ & Grammar & $\begin{array}{c}\text { Org. } \\
\text { Pretest }\end{array}$ & $\begin{array}{l}\text { Org. } \\
\text { Gain }\end{array}$ & $\sigma$ \\
\hline & & & & $\begin{array}{l}\text { Poor } \\
n-15\end{array}$ & 3.49 & 1.92 & 1.79 \\
\hline \multirow{2}{*}{$\begin{array}{l}\text { L1 } \\
\mathrm{n}-31\end{array}$} & & & & $\begin{array}{l}\text { Better } \\
n=16\end{array}$ & 4.39 & 3.06 & 2.73 \\
\hline & & & & $\begin{array}{l}\text { Poor } \\
n=18\end{array}$ & 4.34 & 2.15 & 2.95 \\
\hline \multirow{2}{*}{$\begin{array}{l}L 2 \\
n=18\end{array}$} & & & & $\begin{array}{l}\text { Better } \\
n=18\end{array}$ & 4.88 & 2.37 & 3.05 \\
\hline & & & & $\begin{array}{l}\text { Poor } \\
n=20\end{array}$ & 4.80 & 0.54 & 2.05 \\
\hline $\begin{array}{l}\text { Comp. } \\
n=37\end{array}$ & & & & $\begin{array}{l}\text { Better } \\
n=17\end{array}$ & 4.38 & 1.56 & 3.09 \\
\hline
\end{tabular}

the tiny difference ("statistical significance" notwithstanding) between the mean English organizational gains made by the groups taught writing in their L1 and L2.

Uzawa and Cumming (1989), in reference to Canadian learners of Japanese, ask whether writing in a "distinctly foreign language" might "differ more markedly from mother tongue or second language composition" (pp. 178-179). It does appear that we must be careful not to generalize findings made in the second language context to the foreign language classroom, for example, expecting that transfer of academic skills "will occur," given exposure and motivation (Cummins, 1991a, p. 77).

The EFL situation may differ from the ESL and the native language contexts largely in the degree of grammatical proficiency possessed by students. Carrell (1991) speculates, in reference to reading research, that foreign language and second language learners may differ largely in their "absolute level of proficiency in the second language" (p. 168). It may be a lot harder for students in a foreign setting, where they are unable to "emulate the behavior of native speakers of the second language in their local surroundings" 
(Uzawa \& Cumming, 1989, p. 189), to attain the necessary level of grammatical proficiency required for efficient L1-to-L2 transfer of skills.

Many ESL students may well possess the grammatical proficiency that permits such transfer-just as we can assume the Icelandic learners in the present study's Group L2 possessed the Icelandic grammatical proficiency that allowed them to transfer these skills, learned in English, to their L1 writing-but many other EFL students may not possess sufficient English grammatical proficiency. Perhaps these less able EFL writers with poor English grammatical proficiency need to devote far more of their memory capacity to finding the right words and constructions, leaving less capacity to deal with organization.

As a curricular approach meant to improve English writing, L1 instruction should probably be restricted to those learners who possess a high level of English grammatical proficiency-a level, it should be added, that motivated, exposed ESL learners may reach more quickly than their EFL counterparts. In discussing the pedagogical implications of her L2 reading study, Carrell (1991) states, "Some readers, especially foreign language readers, especially those at lower proficiency levels, may need relatively greater help with second language skills in order to transfer their good reader skills from their native language" (p. 169). The present study suggests giving similar advice to teachers of L2 writing. EFL and ESL teachers should be aware of the potential usefulness of the L1 in teaching writing, but should realize that the extended use of students' native language may not be especially beneficial for those whose English grammatical proficiency is low.

\footnotetext{
Notes

${ }^{1}$ The students of this study began learning Danish as a foreign language at age 11 and English at 12. In almost all cases, however, their English is far more advanced than their Danish proficiency.

${ }^{2}$ Others have referred to this competence as language proficiency. I use the term grammatical proficiency to make a sharp distinction between it and writing skill.

${ }^{3}$ Bereiter and Scardamalia (1983) make the following distinction between "low road" and "high road" writers: Whereas "low road" writers' mental capacity is applied exclusively to the task at hand-transcribing language-for "high road" writers "writing becomes a task of representing meaning" while simultaneously devoting "conscious attention to style" (p. 25).

${ }^{4}$ In a survey of a randomly selected week of broadcasting on Icelandic State Television $50 \%$ of the programming was in English with Icelandic subtitles. A newspaper's entertainment guide on a randomly selected day revealed the following entertainment being performed or shown in Reykjavik: 2 plays in Icelandic; 1 opera in Italian; 2 films in Icelandic; 3 foreign (animated) films dubbed in Icelandic; and 25 (different) films in English, with Icelandic subtitles.

${ }^{5}$ Phillipson (1992) argues that "English can be regarded as a second language rather than a foreign language in the Nordic countries" (p. 25). In terms of the commercial, professional, and social value of English in Iceland, its status approaches-though, I would say, does not reachthat of a second language. A survey of four bachelor's-level courses in nursing at the University of Iceland revealed that 22 out of the 25 articles or textbooks recommended for reading were in English. According to the Educational Testing Service (ETS, 1992), the Test of English as a
} 
Foreign Language (TOEFL) was administered 1,000 times in Iceland between July 1989 and June 1991. This amounts to 395 examinations administered per 100,000 inhabitants. During the same period, 6 examinations were administered per 100,000 inhabitants in Brazil, 42 in France, 123 in Israel, and 206 in Japan. Only Hong Kong examinations $(1,845$ per 100,000) were more numerous per capita. Clearly many Icelanders consider studying in North America.

${ }^{6}$ Research in the field is reviewed in depth by Houghton and Hoey (1983). An overview of recent developments has been compiled by Martin (1991)

${ }^{7}$ Materials on essay writing currently being used in Icelandic secondary schools were examined. The similarity of Icelandic and English language models may have to do with the fact that Icelandic text books have been influenced by English language manuals.

${ }^{8}$ The reason for the smaller numbers at Schools II and III (where students rotate between classes according to individual scheduling) is that these were the students whose English and Icelandic classes I could observe, and which could be controlled.

${ }^{9}$ All identification was removed from the tests, which were coded with random numbers, and the master coding sheet was locked away. Raters were unaware of student identity, treatment, school, and in every case were unable to tell whether they were rating a pre- or posttest.

${ }^{10}$ It may be that the score for Argument relates to Length in the English (and not in the Icelandic) essays because students were less able to write a succinct argument in the L2.

${ }^{11}$ Multiple regression analyses were employed because of the large number of variables. Aside from treatment ( $\mathrm{L} 1, \mathrm{~L} 2$, comparison), the effects of grammatical proficiency, school (I, II, III), gender, order of pre- and posttest (Pre-A followed by Post-B, versus $B$ followed by $A$ ), and students' major field of study were all examined.

${ }^{12}$ Absenteeism and scheduling problems meant that not all 126 students wrote the Icelandic tests.

${ }^{13} \mathrm{~L} 1$ grammar scores were not analyzed for pre- to posttest gain.

${ }_{14}^{14}$ Twenty-two students scored 8 for Organization on the pre-test: nine were in Group L1, 10 in Group L2 and three in Group C. Only four of these 22 improved their Organization score on the posttest: two in Group L1 and two in group L2. These four seem to be the exceptions proving the rule that the better essay writers did not improve as a result of the instruction provided.

${ }^{15}$ Students' pre- and posttest English Grammar scores were averaged (added then divided by 2) to obtain this score. Normally, pre- and posttest Grammar scores were similar $(r=.59)$. However, the rationale behind averaging them was to obtain a "mid-term" score, as well as to modify any possible rating errors. This average grammar score is the mean of four separate blind holistic ratings- - two from the pre-test and two from the posttest.

${ }^{16}$ The correlation between (average) Grammar score and pre-test Organization scores is 0.3 .

\section{The Author}

Robert Berman is a Canadian doctoral candidate at Lancaster University, UK. He has taught ESL and EFL at secondary schools and universities in Ontario and Iceland. His $\mathrm{PhD}$ research, from which this article stems, has been made possible through support from the Social Sciences and Humanities Research Council of Canada in the form of a doctoral fellowship. E-mail enquiries (addressed to rberman@rhi.hi.is) are welcome. 
References

Alderson, J.C. (1984). Reading in a foreign language: A reading problem or a language problem? In J.C. Alderson \& A.H. Urquhart, (Eds.), Reading in a foreign language. London: Longman.

Bereiter, C., \& Scardamalia, M. (1983). Does writing have to be so difficult? In A. Freedman, I. Pringle, \& J. Yalden (Eds.), Learning to write: First language/second language. London: Longman.

Carrell, P.L. (1991). Second language reading: Reading ability or language proficiency? Applied Linguistics, 12, 159-179.

Clarke, M.A. (1980). The short circuit hypothesis of ESL reading-Or when language competence interferes with reading performance. Modern Language Journal, 64, 203-209.

Cumming, A. (1990). Writing expertise and second language proficiency. Language Learning, $39,81-141$.

Cummins, J. (1991a). Conversational and academic language proficiency in bilingual contexts. Association Internationale de Linguistique Appliquée, 8, 75-89.

Cummins, J. (1991b). Interdependence of first- and second-language proficiency in bilingual children. In E. Bialystok (Ed.), Language processing in bilingual children. Cambridge: Cambridge University Press.

ETS. (1992). Newsline: International testing and training programs. Princeton, NJ: Educational Testing Service.

Houghton, D., \& Hoey, M.P. (1983.) Linguistics and written discourse: Contrastive rhetorics. In R.B. Kaplan, R.L. Jones, \& G.R. Tucker (Eds.), Annual review of applied linguistics, III. Rowley, MA: Newbury House.

Martin, J.E. (1991). Contrastive rhetoric: Implications of a revised approach to text. ERIC document ED 329118.

Phillipson, R. (1992). Linguistic imperialism. Oxford: Oxford University Press.

Ringbour, H. (1992). On L1 transfer in L2 comprehension and production. Language Learning, $42,85-112$.

Scardamalia, M. (1981). How children cope with the cognitive demands of writing. In C.H. Frederiksen, M.F. Whiteman, \& J.F. Dominic (Eds.), Writing: The nature, development and teaching of written communication. Hillsdale, NJ: Erlbaum.

Uzawa, K., \& Cumming, A. (1989). Writing strategies in Japanese as a foreign language: Lowering or keeping up the standards. Canadian Modern Language Review, 46, 178-194.

Yau, M.S.S. (1987). Two approaches to improving the writing performance of ESL students. Unpublished doctoral dissertation, University of Toronto, OISE.

\section{Appendix A}

\section{Lesson Plans for the L1 and L2 Essay Writing Classes}

Class 1 ICELANDIC PRE-TEST (Essay topic A or B, randomly assigned)

Class 2 ENGLISH PRE-TEST (Essay topic A or B, randomly assigned)

Class 3 What is a paragraph? What is an essay? Group and individual exercises.

Class $4 \quad$ Audience. Exercise: Improving writing in which the reader has not been kept in mind.

Class 5 Transition devices/connectives. Group \& Individual Exercises. Draft Essay \# 1 handed in. 
Class 8 Essay \# 2 assigned: written in the next class.

Class 9 Draft Essay \#2 written in class.

Class 10 Draft Essay \#2 returned to students. Students rewrite it.

Class 11 Improving an essay's introduction and conclusion.

Class 12 Draft Essay \#3 returned to students. Students rewrite it.

Class 13 ICELANDIC POSTTEST (Icelandic topic, A or B, that was not written as pre-test).

Class 14 ENGLISH POSTTEST (The English topic not written as pre-test).

\section{Appendix B Essay Topics}

English pre-/posttest $A$

Who-or what-is responsible for the violence in the homes and streets of Reykjavik?

English pre-/posttest $B$

Some people say that the young people of Iceland have "an alcohol problem" and that "something should be done." Do you agree?

Icelandic pre-/posttest $A$ (translated)

Do long school holidays hold back secondary school students from doing better at university?

Icelandic pre-/posttest B (translated)

Should cars be banned from downtown Reykjavik?

\section{Appendix C Scoring Guide}

Thesis There should be a thesis statement, i.e. an opinion, of at least one compound sentence in length, located somewhere in the first two paragraphs. For a top score of 4 the thesis statement had to match the assigned essay topic, as well as the content of the essay. Essays beginning with the words Yes or No or I agree were allowed a score of 2 as long as the writer soon made it clear what issue was being addressed. A score 0 was awarded if no thesis was apparent. 
Argument The score for this feature was dependent on the number of noncontradictory, unambiguous points that supported, or logically stemmed from, the thesis. A point could be:

- an item of information or a fact presented to defend the thesis.

- a reference, i.e. a source of information.

- a logical statement presented as an argument. For example, the writer could "prove" that not all youth are problem drinkers by pointing to himself as an example of a non-problem drinker (or a non-drinker).

- "background information" (if relevant): Some essays began with this sort of information, which was meant to put the thesis in perspective.

On the other hand, seemingly irrelevant information caused deductions. Conclusion The writer was expected to either reiterate the essay's thesis or summarize its main points. A score of 4 was awarded if one of these requirements was fulfilled. Raters kept in mind that the essays were done quickly in class, and permitted the conclusion to be a short statement. A score of 0 was awarded if no conclusion was attempted.

ORGANIZATION The scores for Thesis, Argument and Conclusion were added.

Grammar A separate 0-to-4 holistic score for "grammar" paid attention largely to syntax and vocabulary. Incorrect spelling was not penalized as long as words were spelled phonetically correctly (e.g. lite would be accepted for light)

Essays receiving a low Grammar score tended to exhibit, in decreasing order of occurance:

- non-standard word order (and was it very fine thing to do, but not plainly perfect);

- omissions (they think no need of having higher price);

- redundancies (these kids are not all of them punks);

- incorrect lexical choice (Europeans drink all days);

- verb errors, including lack of agreement with subject (we wants), and incorrect form (can made);

- other errors in syntax.

\section{Appendix D}

Interrater Reliability: Pearson Correlations

Thesis

Argument

Conclusion

ORGANIZATION

Grammar

all: $p<.01$

\section{English Essays}

.80

.73

.87

.87

.80
Icelandic Essays

.77

.77

.81

.85

.74 


\section{Appendix E}

A. Factor Analysis of Icelandic Essay Scores:

Rotated Factor Matrix

\begin{tabular}{lccl}
\hline & $\begin{array}{l}\text { FACTOR 1 } \\
\text { (Organization) }\end{array}$ & $\begin{array}{l}\text { FACTOR2 } \\
\text { (Fluency) }\end{array}$ & $\begin{array}{l}\text { FACTOR 3 } \\
\text { (Length) }\end{array}$ \\
\hline $\begin{array}{l}\text { Conclusion } \\
\text { Argument }\end{array}$ & .62823 & & \\
$\begin{array}{l}\text { Thesis } \\
\text { Grammar }\end{array}$ & .55982 & & \\
$\begin{array}{l}\text { Register } \\
\text { Length }\end{array}$ & .51952 & .79614 & \\
Paragraphs & .40889 & .51830 & \\
\hline
\end{tabular}

B.Factor Analysis of English Essay Scores:

Rotated Factor Matrix

\begin{tabular}{lcll}
\hline & $\begin{array}{l}\text { FACTOR 1 } \\
\text { (Organization) }\end{array}$ & $\begin{array}{l}\text { FACTOR 2 } \\
\text { (Fluency) }\end{array}$ & $\begin{array}{l}\text { FACTOR 3 } \\
\text { (Length) }\end{array}$ \\
\hline $\begin{array}{l}\text { Conclusion } \\
\text { Thesis }\end{array}$ & .70649 & & \\
Argument & .60023 & & \\
Grammar & .37877 & .31363 & .36387 \\
Register & .37080 & .76275 & \\
Transitions. & .30959 & .61735 & \\
Length & .39317 & .37656 \\
Paragraphs & .49066 & & .79290 \\
\hline
\end{tabular}




\section{Appendix $\mathrm{F}$}

A. Multiple Regression Analysis: Organization Score Gains $(n=126)$

\begin{tabular}{lrrrrr}
\hline Variable $^{*}$ & $B$ & SE B & Beta & \multicolumn{1}{c}{ S } & Sig T \\
\hline Grammar \# & .65 & .22 & .25 & 2.96 & .0037 \\
L1 Instruction & .88 & .52 & .16 & 1.71 & .0899 \\
Pre-test + & .20 & .08 & .21 & 2.41 & .0173 \\
L2 Instruction & 1.43 & .50 & .27 & 2.86 & .0050 \\
(Constant) & 3.15 & .65 & & 4.80 & .0000 \\
\hline
\end{tabular}

* Note that to measure the effect of Language of Instruction, the Comparison Group was used as the control group. \# Grammar=Mean of pre- and posttest grammar scores.

+ Pre-test=Pre-test score for Organization (Thesis + Argument + Conclusion)

B. Multiple Regression Analysis: Organization Scores of the "Less Able" Writers $(n=104)$

\begin{tabular}{lrrrrl}
\hline Variable & $B$ & SE $B$ & Beta & $T$ & Sig T \\
\hline Grammar & .65 & .24 & .26 & 2.73 & .0076 \\
L1 Instruction & .97 & .57 & .18 & 1.70 & .0925 \\
Pre-test & .27 & .13 & .19 & 2.01 & .0473 \\
L2 Instruction & 1.23 & .54 & .24 & 2.26 & .0257 \\
(Constant & 2.97 & .82 & & 3.65 & .0004 \\
\hline
\end{tabular}

